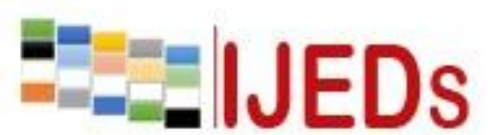

http://ijeds.ppj.unp.ac.id/index.php/IJEDS

\title{
THE EFFECT OF LEARNING DISCIPLINE ON LEARNING ACHIEVEMENT OF CLASS X STUDENTS IN VOCATIONAL HIGH SCHOOL 5 PADANG
}

\author{
*Silvia Marti Veri ${ }^{1}$, Nizwardi Jalinus ${ }^{2}$, Hasan Maksum ${ }^{3}$, Indah Permata Edi ${ }^{4}$, \\ Yumn Jamilah ${ }^{5}$ \\ ${ }^{1}$ Magister Student of Faculty of Engineering, Universitas Negeri Padang \\ ${ }^{2}$ Machine Lecture, Faculty of Engineering, Universitas Negeri Padang \\ ${ }^{3}$ Automotive Lecture, Faculty of Engineering, Universitas Negeri Padang \\ ${ }^{4}$ Magister Student of Faculty of Engineering, Universitas Negeri Padang \\ ${ }^{5}$ Magister Student of Faculty of Engineering, Universitas Negeri Padang
}

Email: silviamartiveri@yahoo.co.id

*Corresponding Author, Received: November 12, 2019, Revised: December 10, 2019, Accepted: December 21, 2019

\begin{abstract}
The research objective is to analyze the discipline of learning on learning achievement at Vocational High School 5 Padang class X. This study uses a correlational quantitative research type. Based on the research results obtained that there is a positive and significant relationship of learning discipline to the learning achievement of students of class X in Vocational High School 5 Padang of $11.97 \%$.
\end{abstract}

\section{Keywords :}

\section{INTRODUCTION}

At present the reality in Indonesia is that the quality of education of students is low. Lately often seen many events that show that to find the identity of adolescents or their identities adolescents commit negative behavior. Sometimes these negative behaviors they can from the often they access social media without filtering out any information they receive. Negative behaviors that are generally considered common among adolescents include irresponsibility, disrespect for teachers, undisciplined, not independent, lazy to learn and behave rudely towards peers, because some in academic matters that result in poor mastery of children on subject matter and achievement in school [1]. As these behaviors develop, many of these students make it the wrong culture among students. one of which is caused by the incessant flow of globalization 


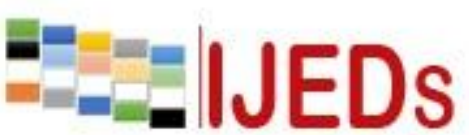

http://ijeds.ppj.unp.ac.id/index.php/IJEDS
International Journal of Educational Dynamics

Vol. 2 No. 1 (pp. 263-273) Desember 2019

p_ISSN 2655-4852

e_ISSN 2655-5093

and global science and technology that hit Indonesia, especially in urban areas. The many cases of student involvement in brawls, school drug use and other forms of juvenile delinquency are far from the description of educated students who are virtuous and responsible. Based on the increasingly apprehensive adolescent problems, it shows that in Indonesia the character possessed by teenagers is still low. Research conducted by [2] found that boys have weaker characters than girls. Previous studies found that boys are more susceptible to having negative behaviors compared to girls. The problem of the low character of students becomes very worrying and must be handled wisely and well. Basically there are many factors that are able to influence student learning achievement ranging from the characteristics of the individual itself to the environment both in the family and school. One factor that occurs is the excessive use of social media. Social media is mostly used by students as a means of communication, finding friends in cyberspace and looking for learning material. But not infrequently the communication that is done is something that is not too important and makes it easy for them to have many friends, because social media is connected to the whole world. So being active on social media is more important than repeating lessons and learning which they find boring. The situation resulted in a lot of time wasted and disrupted student activities, such as study schedules, eating, sleeping, socializing with the real world, and so on. So that the teaching and learning process lived in school and even learning at home is reduced, because the amount of time spent using social media so that students are too busy accessing and playing with fun in social media, so that children's learning interest is disrupted which causes learning achievement decreases.

Apart from social media, strong learning achievements will also be influenced by the emergence of self-discipline where that discipline is something regarding one's self control of the forms of rules. A student needs to have a disciplined attitude by doing exercises that strengthen himself to always get used to being obedient and enhance selfcontrol. Discipline that arises from his own awareness will be more stimulating and long-lasting compared to the attitude of discipline that arises because of the supervision of others. High discipline attitude is needed in learning situations, because only in situations of discipline can the teacher's knowledge, experience, and expertise work effectively. The attitude of students who have high learning discipline will always carry 


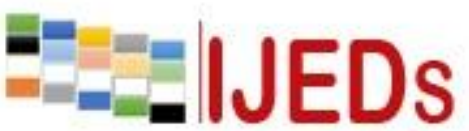

http://ijeds.ppj.unp.ac.id/index.php/IJEDS
International Journal of Educational Dynamics

Vol. 2 No. 1 (pp. 263-273) Desember 2019

p_ISSN 2655-4852

e_ISSN 2655-5093

out the activity of learning on a regular basis, completing tasks on time, participating in all learning activities at school, diligently reading textbooks. Students who have the attitude of their discipline will have high responsibilities. Relation to the process of learning activities of a child who is accustomed to being disciplined will be able to use the learning time as well as possible, both at home and at school.

Discipline can grow and be fostered through training, education or inculcation of habits that must begin in the family environment, starting in childhood and continue to grow so that it becomes a stronger discipline. As mentioned by Joko Sumarno "that the term discipline is obedience and obedience that arises because of the awareness and encouragement in that person". Without good discipline the atmosphere of a positive school discipline provides calm and orderly support for the learning process. Reducing the intensity of access to social media and increasing discipline of learning play an important role in learning achievement. With behavior that is aware of education, and the discipline of learning that students become diligent in the teaching and learning process and by improving the quality of learning, the quality of student achievement can be realized properly. Students who in the learning process have a strong attitude and discipline will succeed in their learning.

Learning achievement is one result of a process of teaching and learning activities. Learning achievement serves as an indicator of student success in a subject. According to [3] "Learning achievement is an indicator and quantity of knowledge which is dominated by students". [4] defining learning achievement is a proof of learning success or the ability of a student to carry out his learning activities in accordance with the weight achieved. Learning achievement is the result obtained by students after going through the learning process to find out what they do not know and is a maximum measure of the level of success achieved by students after conducting the learning process for a period of time determined together in an educational institution. Achievement of student learning achievement can be seen through the implementation of the evaluation of learning outcomes conducted by teachers of students which are proven and demonstrated through the value of the results of tests or examinations taken by students. Good learning achievement is the thing most coveted by students who are learning and said to be achieved if students experience the development and improvement of expected behavior according to learning objectives. Success in learning depends on each individual, students differ from one another in the achievement of learning achievement, but basically the expected results are high learning achievement. 


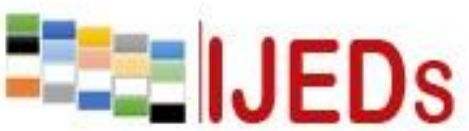

http://ijeds.ppj.unp.ac.id/index.php/IJEDS
International Journal of Educational Dynamics

Vol. 2 No. 1 (pp. 263-273) Desember 2019

p_ISSN 2655-4852

e_ISSN 2655-5093

Based on interviews, discussions and observations of researchers with the principal and vice principals in the fields of curriculum, student field and several teachers and students of SMKN 5 Padang on March 4 2019, data on the number of students in 2018/2019 class X amounted to 561, and get information that students tend to be bored and uncomfortable with the school environment that is not good and uncomfortable so that the lessons become boring and not conducive to learning so that students are not motivated in learning and not achieving good learning outcomes. Based on the information the researcher obtained through the vice principal in the field of curriculum, the school implemented a remedial program and the aim was to complete the grades of students for the implementation of the learning process that there were still not yet mastered students. And while SMKs are required to be able to produce graduates who are experts in the fields in accordance with their respective departments so that they are ready to enter the world of work and industry. Based on the description of diaatas and identified phenomena, many factors are thought to influence the learning achievement of students of Vocational High School 5 Padang. This research will be more complete in discussing the problem to be examined, if all the factors described in the identification of the problem above can be revealed. However, given the wide scope of the problem and the limitations of the researchers, this study is limited to only two (3) variables which are thought to be very dominant to have an influence on student learning outcomes at Vocational High School 5 Padang, namely: social media variables, learning discipline and learning achievement.

Furthermore, the formulation of the problem is: is there a significant influence of learning discipline on student achievement in class X Vocational High School 5 Padang. The purpose of this study is to Analyze the learning discipline of learning achievement in Vocational High School 5 Padang class X. This research is relevant to the research conducted by [5] with the title "The Effect of School Environment and Learning Motivation on Student Achievement in Class X SMK Pasundan 1 Bandung. The results revealed that Tengku Umar Sumedang Vocational School was included in the good category with a percentage of 58.9 students' learning motivation with a good category with a percentage of $69.25 \%$ and a sufficient student learning presentation with a percentage of $7.38 \%$.

Furthermore, this study is also relevant to research conducted by [6] "The Intensity Relationship of Accessing Facebook with Learning Motivation of Tenggarong Seberang High School 2 students." The results of the study concluded that the low intensity of accessing Facebook students was followed by high motivation in learning. And conversely the more often students access Facebook, the lower the motivation to learn they have. Then it is also relevant to his research [7] "The Effect of Internet Use on Student Learning Achievement in Economics 


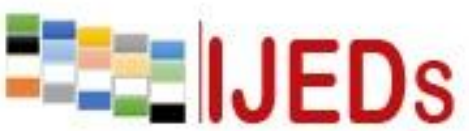

http://ijeds.ppj.unp.ac.id/index.php/IJEDS

\section{International Journal of Educational Dynamics}

Vol. 2 No. 1 (pp. 263-273) Desember 2019

p_ISSN 2655-4852

e_ISSN 2655-5093

Class X in Smhi Budman War II". The results of the study concluded the magnitude of the effect of the use of the internet on student achievement in economic class X in Budhi Warman II High School. The results showed that the coefficient of determination was $64 \%$. So from the above information it can be concluded that the use of the internet affects the economic subjects of class $\mathrm{x} 64 \%$ while $36 \%$ is determined by other factors namely learning styles, environment and teachers in mastering internet learning media.

\section{METHOD}

This research is a study that uses quantitative research types using correlational research types. According to [8] "correlational research is research intended to determine the correlation between two or several variables". The magnitude or height of the relationship is expressed in terms of correlation coefficients. This study aims to reveal the relationship between one variable with another variable. The sampling technique used is proportional random sampling. The sample in this study was class $\mathrm{X}$ students at Vocational High School 5 Padang as many as 72 students. The research instrument used in this study was a non-test instrument in the form of a questionnaire. The instrument test was conducted to expert validators and to teachers outside the study sample. The data source used in this study is primary data obtained directly from respondents by distributing questionnaires to class $\mathrm{X}$ students at Vocational High School 5 Padang who have been selected as samples. And also secondary data that has been first collected and reported by people or agencies outside the researchers themselves, such as data on the number of students in Vocational High School 5 Padang. Data analysis was carried out by testing normality, linearity and hypothesis testing.

\section{RESULTS AND DISCUSSION}

This chapter will discuss the analysis and discussion of research results in accordance with data and facts found in the field, the results of the study were obtained from a questionnaire distributed to 72 respondents, the questionnaire contained statements concerning the effect of the discipline of learning (X) on learning outcomes (Variable $\mathrm{Y}$ ) class $\mathrm{X}$ at Vocational High School 5 Padang. The results of this study are reported in accordance with the objectives proposed in the study. Furthermore, to see the effect of the discipline of learning (X) on learning outcomes (Variable Y), the hypothetical analysis requirements (normality and 


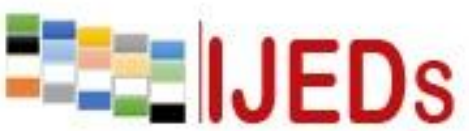

http://ijeds.ppj.unp.ac.id/index.php/IJEDS
International Journal of Educational Dynamics

Vol. 2 No. 1 (pp. 263-273) Desember 2019

p_ISSN 2655-4852

e_ISSN 2655-5093

linearity test) are carried out, hypothesis testing and discussion of research results. The description of the data illustrates the effect of learning discipline (X) on learning outcomes (Variable Y) of class X at Vocational High School 5 Padang. Data obtained by distributing questionnaires as many as 35 items distributed to 72 respondents. This data description is done to describe the state of each variable that includes the number of values, mean, median, mode, minimum value, maximum value, range, interval, class length, variance and standard deviation. Table 1 shows the basic statistical calculations of the two variables.

\begin{tabular}{cccc}
\multicolumn{4}{c}{ Table 1. Statistical Calculation Results for Variables X and Y } \\
\hline No & Statistik & Variabel X & Variabel Y \\
\hline 1 & N & 72 & 72 \\
2 & Jumlah Nilai & 10085 & 6091 \\
3 & Mean (rata-rata) & 140,07 & 84,60 \\
4 & Median & 138 & 86 \\
5 & Modus & 128 & 86 \\
6 & Nilai Maksimum & 175 & 100 \\
7 & Nilai Minimum & 110 & 70 \\
8 & Range & 65 & 30 \\
9 & Interval & 8 & 8 \\
10 & P. Kelas Interval & 9 & 4 \\
11 & Varians & 219,19 & 56,33 \\
12 & Standard Deviasi & 14,81 & 7,51 \\
\hline
\end{tabular}

Data on learning discipline variables were collected through a questionnaire consisting of 35 statements that had been tested for validity and reliability. Furthermore, the questionnaire was given to 72 respondents to fill out. From the research data it was found that the distribution of answer scores spreads the lowest 110 and the highest 175 . Based on the distribution of the scores obtained an average (mean) of 140.07 middle score (median) 138, scores that appear a lot (mode) 128, variance 219.19 and standard deviation (standard deviation) 14.81. The following is a clear description of the distribution of scores about the discipline of learning, can be seen in table 2.

Table 2. Variable Frequency Distribution Learning discipline

\begin{tabular}{ccccc}
\hline No & $\begin{array}{c}\text { Interval } \\
\text { Skor }\end{array}$ & $\begin{array}{c}\text { Frekuensi } \\
\text { Mutlak }\end{array}$ & $\begin{array}{c}\text { Variabel X } \\
\text { Frekuensi } \\
\text { Relatif (\%) }\end{array}$ & $\begin{array}{c}\text { Frekuensi } \\
\text { Kumulatif (\%) }\end{array}$ \\
\hline 1 & $110-118$ & 5 & 6,94 & 6,94 \\
2 & $119-127$ & 5 & 6,94 & 13,89 \\
3 & $128-136$ & 25 & 34,72 & 48,61 \\
4 & $137-145$ & 14 & 19,44 & 68,06 \\
5 & $146-154$ & 8 & 11,11 & 79,17
\end{tabular}


http://ijeds.ppj.unp.ac.id/index.php/IJEDS

\begin{tabular}{ccccc}
6 & $155-163$ & 10 & 13,89 & 93,06 \\
7 & $164-172$ & 3 & 4,17 & 97,22 \\
8 & $173-181$ & 2 & 2,78 & 100,00 \\
\hline Jumlah & $\mathbf{7 2}$ & $\mathbf{1 0 0}$ & \\
\hline
\end{tabular}

Learning achievement variable data is collected through items of learning achievement test items consisting of 30 questions that have been tested for validity and reliability, as well as indexes of difficulty and difference. Furthermore, the questionnaire was given to 72 respondents to be filled. From the research data it is known that the distribution of the lowest scores is 70 and the highest is 100 . Based on the distribution of the scores obtained an average (mean) of 84.60, a middle score (median) 86, a score that appears a lot (mode) 86, variance of 56.33 and standard deviation (standard deviation) 7.51. Here is a clear picture of the distribution of learning outcomes, can be seen in table 3 .

Table 3. Variable Frequency Distribution of Learning Outcomes

\begin{tabular}{ccccc}
\hline No & $\begin{array}{c}\text { Interval } \\
\text { Skor }\end{array}$ & $\begin{array}{c}\text { Frekuensi } \\
\text { Mutlak }\end{array}$ & $\begin{array}{c}\text { Variabel Y } \\
\text { Frekuensi } \\
\text { Relatif (\%) }\end{array}$ & $\begin{array}{c}\text { Frekuensi } \\
\text { Kumulatif (\%) }\end{array}$ \\
\hline 1 & $70-73$ & 8 & 11,11 & 11,11 \\
2 & $74-77$ & 7 & 9,72 & 20,83 \\
3 & $78-81$ & 10 & 13,89 & 34,72 \\
4 & $82-85$ & 12 & 16,67 & 51,39 \\
5 & $86-89$ & 15 & 20,83 & 72,22 \\
6 & $90-93$ & 13 & 18,06 & 90,28 \\
7 & $94-97$ & 4 & 5,56 & 95,83 \\
8 & $98-101$ & 3 & 4,17 & 100,00 \\
\hline & Jumlah & $\mathbf{7 2}$ & $\mathbf{1 0 0}$ & \\
\hline
\end{tabular}

In this chapter the analysis and discussion of research results will be discussed in accordance with the data and facts found in the field, the results of the study were obtained from a questionnaire distributed to 72 respondents, the questionnaire contained statements concerning the effect of learning discipline on the learning achievement of class X students at SMK Negeri 5 Padang. The results of this study are reported in accordance with the objectives proposed in the study. Furthermore, to see the effect of the discipline of learning on student achievement in class X at SMK Negeri 5 Padang, the terms of hypothesis analysis (normality and linearity) are conducted, the hypothesis test and discussion of the results of the study. 


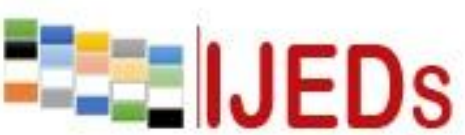

http://ijeds.ppj.unp.ac.id/index.php/IJEDS
International Journal of Educational Dynamics

Vol. 2 No. 1 (pp. 263-273) Desember 2019

p_ISSN 2655-4852

e_ISSN 2655-5093

Normality test is used to determine whether the population data is normally distributed or not [9]. Normality test is done using the Liliefors formula which is calculated manually. The normality test results can be seen in the following table 4:

Table 4. Normality Test

\begin{tabular}{lllcccc}
\hline No. & Kelas & $\mathbf{N}$ & $\mathbf{L}_{\mathbf{0}}$ & $\mathbf{L}_{\mathbf{t}}$ & Perbandingan & Ket \\
\hline 1. & $\mathrm{X}$ & 72 & 0,0122 & 0,1044 & $\mathrm{~L}_{\text {hitung }}<\mathrm{L}_{\text {tabel }}$ & Normal \\
2. & $\mathrm{Y}$ & 72 & $-0,0078$ & 0,1044 & $\mathrm{~L}_{\text {hitung }}<\mathrm{L}_{\text {tabel }}$ & Normal \\
\hline
\end{tabular}

From table 4 it can be seen that the significance score for learning discipline on student achievement is obtained L0 for variable X (learning discipline) of 0.0122, for variable Y (learning achievement) of -0.0078 . While the $\mathrm{Lt}$ value is 0.1044 obtained from the critical L value for the Liliefors test. Because the result is Lhitung < Ltable, the sample is said to have normal distribution. Then the next prerequisite for hypothesis testing can be done.

The linearity test aims to find out whether the learning discipline variable (X) has a linear correlation or not significantly to the learning achievement variable (Y). Linearity test is usually used as a requirement in correlation analysis or linear regression. It can be said that there is a significant linear relationship between variables if the significance is greater than alpha (0.05). The data linearity test results can be seen in the following table 5:

Table 5. Data Linearity Test Results

\begin{tabular}{lcrrc}
\hline Variabel & Sig. & F hitung & F table & Kriteria \\
\hline $\mathrm{X}-\mathrm{Y}$ & 0,05 & $-4,625$ & 1,528 & Linear \\
\hline
\end{tabular}

Based on the linearity test results table above, the value of Fcount $=-4.625$ while Ftable $=1.528$ obtained from the distribution table of $\mathrm{F}$ value at 0.05 significance Because the calculated $\mathrm{F}$ value is greater than Ftable, it can be concluded that there is a significant linear correlation between the variables of learning discipline $(\mathrm{X})$ on learning achievement (Y). Then the hypothesis test can be implemented.

Hypothesis testing is done to prove whether the proposed hypothesis is accepted or rejected, using simple correlation analysis, multiple correlation and significance test. Testing this hypothesis is done manually. A simple correlation test is performed to state 


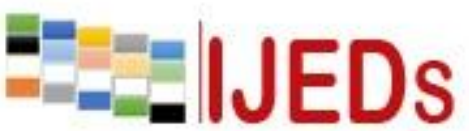

http://ijeds.ppj.unp.ac.id/index.php/IJEDS
International Journal of Educational Dynamics

Vol. 2 No. 1 (pp. 263-273) Desember 2019

p_ISSN 2655-4852

e_ISSN 2655-5093

how much the relationship between one independent variable and one dependent variable. Hypothesis testing aims to test whether the proposed hypothesis is accepted or rejected. The formula used in this test is the Product Moment correlation formula. Simple correlation test is performed using the Product Moment Correlation Test Formula, the results of the Product Moment Correlation test obtained $r$ count value then compared with rtable. Based on the calculation results $r$ test can be seen in table 6 obtained:

Table 6. Simple Correlation Test Summary

\begin{tabular}{cccc}
\hline Hipotesis & $\mathbf{r}_{\text {hitung }}$ & $\mathbf{R}_{\text {tabel }}(\mathbf{5 \% )}$ & Ket \\
\hline $\mathrm{X}-\mathrm{Y}$ & 0,346 & 0,232 & $\mathrm{H}_{1}$ diterima \\
\hline
\end{tabular}

Based on table 6 , the results show that $r$ count $>r$ table, so it can be concluded that the $\mathrm{H} 1$ hypothesis is accepted. So there is a positive and significant effect between learning discipline on learning achievement (X-Y). Furthermore, a significant test was performed. Significance test is carried out using the $t$ test formula, from the $t$ test results obtained tcount then compared with $t$ table. Based on the results of the $t$ test calculations can be seen in table 7 .

Table 7. Summary $\mathrm{t}$

\begin{tabular}{cccc}
\hline Hipotesis & $\mathbf{t}_{\text {hitung }}$ & $\mathbf{t}_{\text {tabel }}(\mathbf{5 \%})$ & Ket \\
\hline $\mathrm{X}-\mathrm{Y}$ & 3,085 & 1,994 & $\mathrm{H}_{1}$ diterima \\
\hline
\end{tabular}

Based on table 7 it can be said tcount $>$ ttable then $\mathrm{H} 1$ is accepted. So it can be concluded that there is a positive and significant influence between learning discipline on learning achievement (X-Y) in Vocational High School 5 Padang.

The results of the analysis of this study contain a description of the data on the effect of learning discipline on learning achievement. Based on this research, it is known that the influence of learning discipline $(\mathrm{X})$ on learning achievement $(\mathrm{Y})$ of class $\mathrm{X}$ students at Vocational High School 5 Padang is $11.97 \%$. The results of data analysis and hypothesis testing show that the hypotheses tested in this study were accepted. Thus, the variable $X$ (learning discipline) has a positive and significant effect on the variable Y (learning achievement). Testing this hypothesis uses a simple correlation that aims to determine the correlation that occurs between learning disciplines to learning 


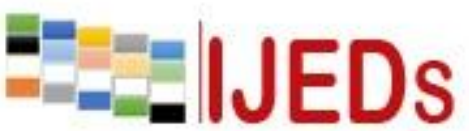

http://ijeds.ppj.unp.ac.id/index.php/IJEDS
International Journal of Educational Dynamics

Vol. 2 No. 1 (pp. 263-273) Desember 2019

p_ISSN 2655-4852

e_ISSN 2655-5093

achievement. Correlation test results obtained for variable $\mathrm{X}$ (learning discipline) with Y variable (learning achievement) is 0.346 while rtable is 0.232 , so rcount $>$ rtable. Then it can be concluded that the correlation is said to be positive and significant and can be continued with a significant test. Significant tests were sought using the test. so that the variable obtained results $t$ count $=3.085$ and $t$ table $=1.994(t$ count $>t$ table $)$ for $X$ (learning discipline) to $\mathrm{Y}$ (learning achievement). Then it can be concluded that $\mathrm{H} 1$ is accepted.

In this study the learning discipline (Variable $\mathrm{X}$ ) provides a sufficient correlation to the learning achievement (Y) of class $\mathrm{X}$ students in Vocational High School 5 Padang which is $11.97 \%$. Then it can be concluded that H1 is accepted, that there is a positive and significant influence between learning discipline on student achievement in class $\mathrm{X}$ at Vocational High School 5 Padang. Then it can be concluded that this study succeeded in proving that the discipline of learning has a positive and significant correlation to the learning achievement of class $\mathrm{X}$ students at Vocational High School 5 Padang.

\section{CONCLUSION}

From the results of the analysis of research on the effect of learning discipline (X) on learning achievement (Variable Y) class X in Vocational High School 5 Padang, it can be concluded that there is a positive and significant influence between learning discipline (X) on learning achievement ( $\mathrm{Y}$ variable) class $\mathrm{X}$ at Vocational High School 5 Padang. Based on simple correlation test calculations, the result is $r$ count $>r$ table $(0.346>0.232)$. So it can be concluded that the correlation is said to be positive, and can be continued with a significant test. Significant tests were sought using the $t$ test. so the results obtained with tcount $=3.085$ while ttable $=1.994$ (tcount $>$ ttable). This value gives the conclusion that there is a positive and significant effect of learning discipline $(\mathrm{X})$ on learning achievement (Variable $\mathrm{Y}$ ) class $\mathrm{X}$ in Vocational High School 5 Padang. Based on the explanation above it can be concluded that the H1 hypothesis in this study was accepted.

\section{REFERENCES}

Evi Nuryani. 2011. Hubungan Intensitas Mengakses Facebook dengan Motivasi Belajar siswa SMA Negeri 2 Tenggarong Seberang. Jurnal Vokasi. Vol 4 (1): 110-119. 
http://ijeds.ppj.unp.ac.id/index.php/IJEDS

Karina, dkk. Membangun Disiplin Belajar Peserta Didik Sejak Dini. Bandung: Alfabeta.

Malinda Puji Ayu Lestari. 2011. Pengaruh Lingkungan Sekolah dan Motivasi Belajar Terhadap Prestasi Belajar Siswa kelas X SMK Pasundan 1 Bandung. Jurnal Pendidikan. Vol 2 (1): 44-51.Puspita Sari. 2006. Disiplin Belajar. Jakarta: Rineka Cipta.

Sugiyono. 2013. Metode Penelitian Kuantitatif Kualitatif dan $R \& D$. Bandung: Alfabeta. Suharsimi, Arikunto. 2013. Prosedur Penelitian. Jakarta: Rineka Cipta.

Toto Widiarto. 2017. Pengaruh Penggunaan Internet Terhadap Prestasi Belajar Siswa Pada Mata Pelajaran Ekonomi Kelas X Di Sma Budhi Warman II. Jurnal Pendidikan Teknik. Vol 1 (1): 30-40.

Winkel. 1996. Belajar dan Pembelajaran. Yogyakarta: Andi.

Zainal, Arifin. 2013. Kiat Meningkatkan Prestasi Belajar Peserta Didik. Jakarta: Tristo. 